American J. of Engineering and Applied Sciences 3 (1): 1-6, 2010

ISSN 1941-7020

(C) 2010 Science Publications

\title{
Effect of Polypropylene Fibers on the California Bearing Ratio of Air Cured Stabilized Tropical Peat Soil
}

\author{
Behzad Kalantari, Bujang B.K. Huat and Arun Prasad \\ Department of Civil Engineering, University Putra Malaysia, Serdang, Selangor, Malaysia
}

\begin{abstract}
Problem statement: Peat soil is well known to deform and fail under a light surcharge load and is characterized with low shear strength, high compressibility and high water content. With the rising demand from the construction industry, utilization of these soils is required and suitable technique needs to be found out for stabilizing them. Approach: Model study had been carried to stabilize peat soil using cement as binding agent and polypropylene fibers as additive. Due to high natural water content of the peat soil, the stabilized peat soil samples were kept at normal room temperature and relative humidity for air curing for 90 days. The improvement in the mechanical strength of the stabilized samples was studied by California Bearing Ratio (CBR) test for both, unsoaked and soaked samples. The water-cement ratio of the samples was measured for 180 days to study the improvement in strength over time. Results: The results of CBR tests showed an increase by a factor over 22 for unsoaked condition and 15 for the soaked condition of the stabilized samples. With the addition of the polypropylene fibers to the stabilized peat soil with cement not only improved the strength of the stabilized peat soil but also contributed to considerable amount of uniformity and intactness to the stabilized peat soil samples. It was also observed that as the curing time for the stabilized peat soil continued through 180 days the moisture content continued to decrease as well. Thus the water-cement (w/c) ratio reduced and as a result of cement hydration, the strength stabilized peat soil samples increased in hardness and gained strength through the curing period. Conclusion/Recommendations: Cement and polypropylene fibers can be used to improve the mechanical strength of the soft peat soil by adopting air curing technique.
\end{abstract}

Key words: Peat, cement, polypropylene fibers, stabilization, California bearing ratio, air curing

\section{INTRODUCTION}

Peat is a soil that contains a significant amount of organic materials. It is known to deform and fail under a small surcharge load and is characterized by low shear strength, high compressibility and high water content (Huat, 2004). The different methods (Huat, 2007) available to improve the load carrying capacity of poor soils include; transfer the load to a more stable soil layer without improving the properties of the in situ soil; remove the soft soil and replace it, fully or partially, with better quality fill and; improve the in situ soil properties with different techniques of ground improvement.

Sometimes it may be possible to combine different methods to provide a suitable foundation for the imposed loads. Hebib and Farrell (2003) provide a technique of surface stabilization combined with stabilized cement columns for foundation loads support. Also, Black et al. (2007) in their study used reinforced stone column that not only transfers loads to the lower and stronger layer but also receives lateral support from the weak soil along the way.

To improve the performance of soil with low bearing capacity, cement has been used by many researchers (Ismail, 2002; Baisha, 2005; Kolias, 2005; Chen, 2009). Some studies have also been carried out by researchers (Yetimoglu, 2004; Park, 2005; Tang, 2007; Sivakumar Babu, 2008) to study the influence of fiber inclusion on the mechanical behavior of cemented soil. The reports in the literature show that randomly distributed polypropylene fibers can be used to overcome the drawback of using cement alone such as high stiffness and brittle behavior of the stabilized soil.

Tang et al. (2007) have used fiber and cement to stabilize clayey soil and observed that the fiber reinforcement causes an increase in UCS, shear strength. It is observed that the polypropylene fibers prevent the development and further opening of cracks and accordingly preventing samples from complete

Corresponding Author: Behzad Kalantari, Department of Civil Engineering, University of Putra Malaysia, 43400 UPM, Serdang, Selangor, Malaysia Tel: +601 69046725 Fax: +603 86567129 
failure. The authors could not find any literature on the use of polypropylene fibers to stabilize a peat soil.

In the present model study, peat soil is stabilized with cement as binding agent and also reinforced with polypropylene fibers as chemically non-active additive. Air curing method as described by Kalantari and Huat (2008) is adopted to cure the samples and to strengthen the stabilized peat soil by keeping it in normal room air temperature and humidity without adding water from the outside.

This air curing method causes the high water content of the stabilized peat soil to gradually decrease with time because of the hydration process and resulting in an increase in CBR values.

\section{MATERIALS AND METHODS}

Test materials: Peat soil used in the study were collected as disturbed and undisturbed samples according to AASHTO T86-70 and ASTM D42069 (Bowles,1978; Department of the Army, 1980) from Kampung, Jawa, western part of Malaysia. Table 1 shows the properties of the in situ peat soil. Binding agent used for this study was ordinary Portland cement and its properties are presented in Table 2. Polypropylene fibers, shown in Fig. 1 were used as chemically non-active additive. Its properties are presented in Table 3.

Experimental program: In order to examine the effect of cement admixtures and polypropylene fibers on the CBR values of peat soil, index properties tests on the peat soil have been conducted. The tests include: water content, liquid limit, plastic limit, organic content, specific gravity and fiber content. Shear strength parameters of the undisturbed peat soil has been found out by triaxial test and shear strength is found out by unconfined compressive strength. Rowe cell consolidation test has been carried out to evaluate the compressibility behavior of undisturbed peat soil. The
CBR test has been carried out on the stabilized peat soil (mixture of peat cement and polypropylene fibers) to investigate the increase in strength of the samples.

Peat soil samples used for the CBR tests were at their natural moisture contents and therefore no water was added or removed from the samples during the mixing process of peat, cement and polypropylene fibers.

California Bearing Ratio (CBR): CBR tests have been conducted on the undisturbed peat soil as well as stabilized peat soil with cement and polypropylene fibers. For the stabilized peat soil with cement (mixture of peat soil and cement) the soil samples used were samples at their natural moisture contents of about $200 \%$. Specified dosage of cement and polypropylene fibers were mixed well with the peat soil for uniformity and homogeneity, before molding the samples according to the specified standard.

Stabilized peat soil samples with cement and polypropylene fibers were placed in the CBR mold for air curing for 90 days. CBR tests were performed on samples under both, un-soaked and soaked conditions.

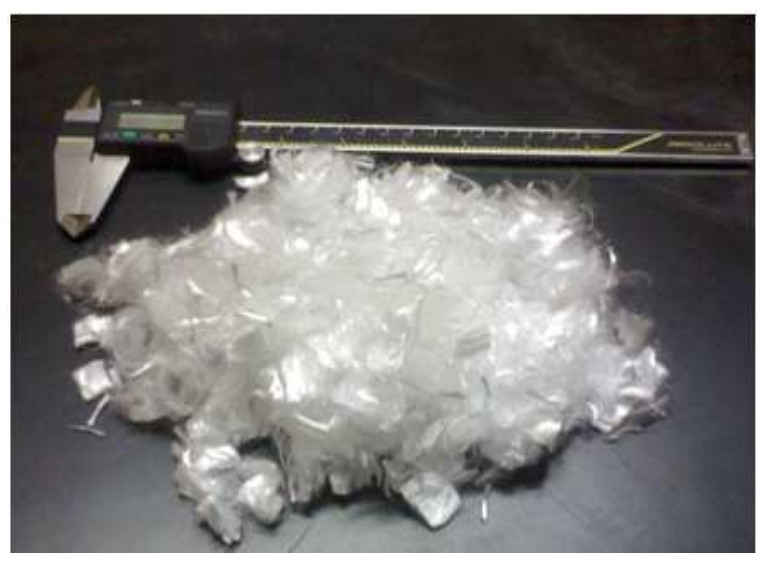

Fig. 1: Polypropylene fibers (Kalantari, 2009)

Table 1: Properties of peat soil (Bowles, 1978; Department of the Army, 1980; Kalantari, 2009; British Standards Institution 1337, 1990)

\begin{tabular}{|c|c|c|}
\hline Properties & Standards & Values \\
\hline Depth of sampling & & $5-1.0 \mathrm{~m}$ \\
\hline Moisture content & ASTM D2216 & $198-417 \%$ \\
\hline Bulk density (in-situ) & & $10.23-10.4 \mathrm{kN} \mathrm{m}^{-3}$ \\
\hline Specific gravity & BS 1337 & 1.22 \\
\hline Classification & ASTM D5715 & Fibrous \\
\hline Liquid Limit & BS 1337 & $160 \%$ \\
\hline Plastic Index & ASTM D424-59 & Non Plasitc \\
\hline Organic content & ASTM D2974 & $80.23 \%$ \\
\hline Optimum moisture content, $\mathrm{w}_{\mathrm{opt}}$ & ASHTO T 180-D & $130 \%$ \\
\hline Dry density, maximum, $\gamma_{\mathrm{d}, \max }$ & ASHTO T 180-D & $4.89 \mathrm{kN} \mathrm{m}^{-3}$ \\
\hline Permeability & ASTM D2434-68 & $1.8 \times 10^{-3} \mathrm{~m} \mathrm{day}^{-1}$ \\
\hline Initial void ratio, $\mathrm{e}_{\mathrm{o}}$ & BS 1337, ASTM D2435-70 & 12.55 \\
\hline Compression index, $\mathrm{C}_{\mathrm{c}}$ & BS 1337, ASTM D2435-70 & 3.64 \\
\hline Recompression index), $\mathrm{C}_{\mathrm{r}}$ & BS 1337, ASTM D2435-70 & 0.49 \\
\hline UCS (undisturbed) & ASTM 2166-6, AASHTO T208-706 & $28.5 \mathrm{kPa}$ \\
\hline CBR (undisturbed) & ASTM D1883-73, AASHTO T 193-63 & $0.782 \%$ \\
\hline
\end{tabular}


Am. J. Engg. \& Applied Sci., 3 (1): 1-6, 2010

Table 2: Chemical compositions of ordinary Portland cement (Neville, 1996)

\begin{tabular}{lc}
\hline Chemical composition & Value (\%) \\
\hline $\mathrm{SiO}_{2}$ & 20.50 \\
$\mathrm{Al}_{2} \mathrm{O}_{3}$ & 6.50 \\
$\mathrm{Fe}_{2} \mathrm{O}_{3}$ & 3.20 \\
$\mathrm{CaO}$ & 62.50 \\
$\mathrm{MgO}$ & 0.95 \\
$\mathrm{SO}_{3}$ & $<0.01$ \\
$\mathrm{Na}_{2} \mathrm{O}$ & $<0.01$ \\
$\mathrm{~K}_{2} \mathrm{O}$ & $<0.01$ \\
\hline
\end{tabular}

Table 3: Properties of polypropylene fibers (Sika.com, 2007)

\begin{tabular}{ll}
\hline Property & Specification \\
\hline Color & Natural \\
Specific gravity & 0.91 \\
Fiber Length & $12 \mathrm{~mm}$ \\
Fiber Diameter & $18 \mathrm{micron}$ \\
Tensile strength & $300-440 \mathrm{MPa}$ \\
Elastic modulus & $6000-9000\left(\mathrm{~N} \mathrm{~mm}^{-2}\right)$ \\
Water absorption & None \\
Softening point & $160^{\circ} \mathrm{C}$ \\
\hline
\end{tabular}

Curing procedure: In order to cure the stabilized peat soil samples with cement and polypropylene fibers, air curing technique described elsewhere ${ }^{[12]}$ has been used. In this technique, the stabilized peat soil samples for CBR tests were kept in normal room temperature of $30 \pm 2^{\circ} \mathrm{C}$ and relative humidity of $80 \pm 5 \%$ without any addition of water from outside. This technique is used to strengthen the stabilized peat soil samples by gradual moisture content reduction, instead of the usual water curing technique or moist curing method which has been a common practice in the past for stabilized peat soil mixed with cement (Axelsson, 2002; Duraisamy, 2006).

The principle of using this air curing method for strengthening stabilized peat is that, peat soil has very high natural water content and when mixed with cement has sufficient water for curing or hydration process to take place and does not need more water (submerging the samples in water) during the curing process. The technique used for curing samples will cause the stabilized peat soil samples to gradually lose moisture content during the curing period and become drier and thereby gain strength.

Cement dosages: For CBR (un-soaked and soaked) tests, each sample consists of peat soil at its natural water content added with 15, 25, 30, 40 and 50\% cement by weight of wet soil, with and without polypropylene fibers as an additive. The amount of polypropylene fibers used for the stabilized CBR soil samples was based on the result obtained from CBR tests to be carried out to determine the optimum percentage by weight of the wet peat soil samples.

Optimum percentage of polypropylene fibers: Polypropylene fibers are usually used in with cement to control cracks in hardened matrix (Duraisamy, Mullik, 2007). The usual dosage recommended for cement mixes varies from $0.6-0.9 \mathrm{~kg} \mathrm{~m}^{-3}$ (Mullik, 2007).

Polypropylene fibers have been used to stabilize clayey soil by researchers (Park, 2005; Tang, 2007; Sivakumar Babu, 2008) and it is reported that around $0.4 \%$ of polypropylene fibers would provide the maximum strength when tested for unconfined compressive strength.

In this study, in order to find the optimum percentage of fiber content for the stabilized peat soil that would provide the maximum strength, peat soil samples at their natural water content were mixed with different percentages of cement and polypropylene fibers and were cured in air for a period of 90 days and then CBR test was performed on them.

The samples examined for this purpose were prepared by adding 5, 15 and $25 \%$ cement and 0.1 , $0.15,0.2$ and $0.5 \%$ polypropylene fibers. The sample which showed the maximum value of CBR after 90 days of curing was chosen as the optimum percentage of polypropylene fibers for further evaluation of strength of the stabilized peat soil.

CBR test procedure for soaked condition: According to AASHTO T193-63 and ASTM D1883-73, the soaking period of CBR samples for normal soil is $96 \mathrm{~h}$ or 4 days (Bowles, 1978). For this study, in-order to investigate the CBR values of the soaked stabilized peat soil, a set of CBR samples prepared with different dosages of cement and polypropylene fibers $(15,25,40$ and $50 \%$ cement with $0.15 \%$ of polypropylene fibers) to soil at its natural water content were cured in air for 90 days and then soaked in water for a period of 5 weeks. During these five weeks of soaking period, the soil samples were weighed periodically for possible weight increase due to increased saturation. When the samples attained a constant weight and no further increase in weight was observed, it was assumed that the samples became completely saturated. The samples were weighed every day for the first 2 weeks, every 2 days during the next 1 week and every 5 days for the last 2 weeks.

\section{RESULTS}

Optimum percentage of polypropylene fibers: The results of increase in CBR values for different cement and polypropylene fibers content are shown in Fig. 2. It appears that the samples with $0.15 \%$ polypropylene fibers gives the maximum percentage increase in of CBR value (ratio of obtained CBR value/highest CBR value) after curing for 90 days. 
Am. J. Engg. \& Applied Sci., 3 (1): 1-6, 2010

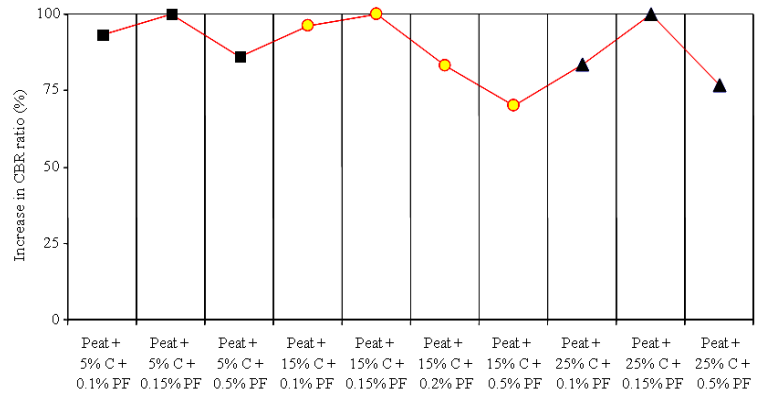

Fig. 2: Different cement and polypropylene fibers content Vs increase in CBR values

Based on the results obtained, it is possible to conclude that $0.15 \%$ of polypropylene fibers as chemically non-active additive would provide the maximum CBR values for the peat soil stabilized with cement. Also, based on the result of this test, $0.15 \%$ of polypropylene fibers have been chosen as an optimum amount for the stabilization of peat soil samples.

CBR soaking test: According to the results shown in Fig. 3, stabilized peat soil sample with $15 \%$ cement reached $100 \%$ saturation and therefore constant weight at the end of four days of soaking period. On the other hand, the sample with the maximum amount of cement $(50 \%)$ reached constant weight (100\% saturation) at the end of six days of soaking. Based on the results of this test, all stabilized peat soil samples were submerged in water for at least 6 days before performing the CBR tests under soaked condition.

Effect of air curing periods on the water-cement ratio of stabilized peat soil: Cement is a common civil engineering material and is used with aggregates and water to gain strength and it hardens with time and gains most of its ultimate compressive strength by 28 days. One of the principal factors affecting the compressive strength of cement-sand is the watercement $(w / c)$ ratio of the fresh mix. Usually, for normal conditions, w/c ratio of about 0.5 is suggested and as w/c for fresh cement-sand increases the compressive strength of the mix will decrease (Road Research Laboratory, 1975) at 28 days.

Therefore, for the hydration or hardening process to take place, not more than an average w/c ratio of 0.5 is required and as the w/c is increased from 0.5 , the compressive strength will decreases.

Figure 4 shows the results of curing time versus w/c ratio. From the Fig. 4, it is observed that the w/c ratio decreases as the curing time increases. The initial w/c ratio of all the stabilized samples containing $5-50 \%$ cement is high and above 0.5.

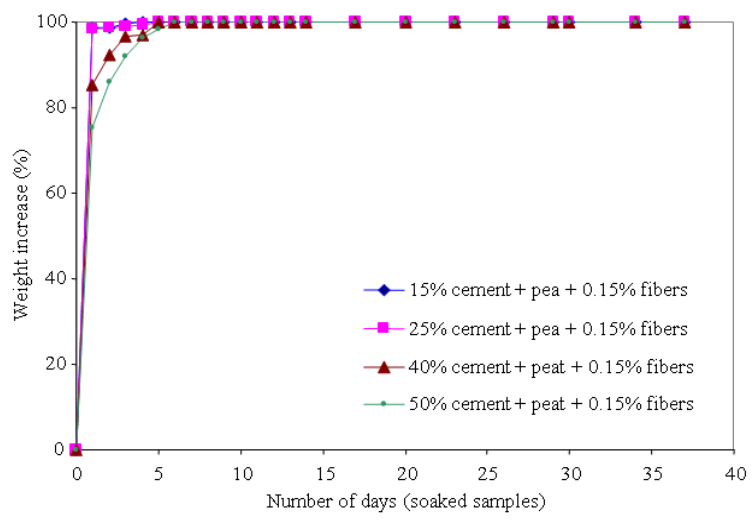

Fig. 3: Soaking time Vs weight increase during soaking (Ismail, 2002)

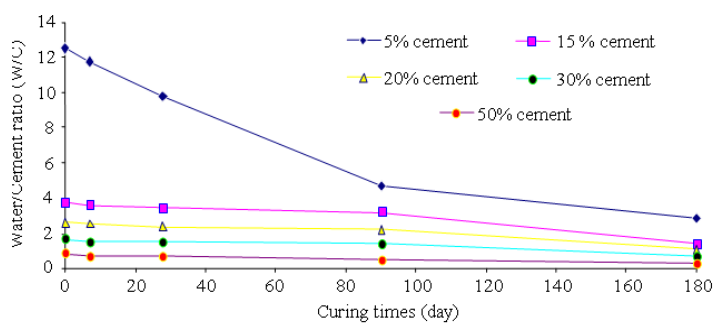

Fig. 4: Air curing periods Vs water-cement ratio for stabilized peat soil samples containing different amount of cement

During the 180 days of air curing, the w/c of the stabilized peat soils never falls below 0.5. This suggests that the initial water content of the natural peat soil is more than sufficient to carry on the hydration process and thus during the curing period there will not be any need for extra water to cure the peat soil stabilized with cement.

Effect of stabilization on CBR value: The results of CBR tests for stabilized peat soil samples with cement and polypropylene fibers after air curing for 90 days are shown on Fig. 5. The CBR value of undisturbed peat soil is $0.785 \%$. With the addition of $50 \%$ cement, it increased to $34 \%$ for unsoaked condition and 30\% for the soaked condition. With the addition of $0.15 \%$ polypropylene fibers with $50 \%$ cement, this increased to 38 and $35 \%$ for unsoaked and soaked conditions. The results indicate that as cement amount in the mixture is increased, the CBR values also increase and addition of polypropylene fibers causes a further increase of the CBR values. Polypropylene fibers as additive contributes more strength to the stabilized peat soil samples. 


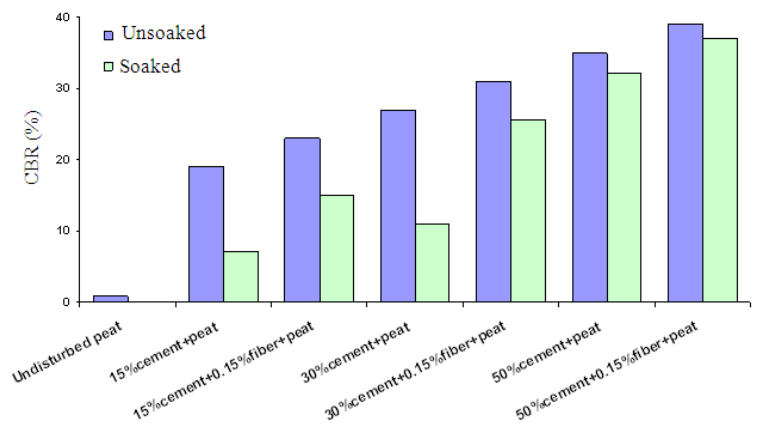

Fig. 5: CBR (\%) values for the undisturbed peat and different percentage of OPC and polypropylene fibers for the stabilized peat soil cured for 90 days

The air curing technique of peat soil stabilized with cement and polypropylene fibers increased the general rating of the in situ peat soil from very poor (CBR from $0-3 \%$ ) to fair and good (CBR from 7 to above 20\%) (Bowles, 1978).

Also, visual inspection of soaked CBR samples depict that the polypropylene fibers not only increase the CBR values but also contribute towards the uniformity and intactness to the stabilized peat soil samples, as compared with the soaked samples with cement only.

\section{DISCUSSION}

The peat soil samples stabilized with cement and polypropylene fibers show an increase in CBR values by as high as $38 \%$. The cement acts as a binding agent and is responsible for the increase in the mechanical strength of the samples. When cement and water are mixed together, the aluminates reacts with the water to form an aluminate-rich gel which reacts with sulfate in solution and the cement start to hydrate, with the formation of calcium silicate hydrate and calcium hydroxide and it gains strength. The polypropylene fibers act a reinforcement to the soil. It appears that it prevents the formation of cracks in the sample and along with cement, binds the soil particles together, leading to an increase in CBR values of the stabilized soil. There appears to be some micro-structural changes resulting from the addition of cement and polypropylene fibers or the interaction between cement and fiber reinforcement which is responsible for the increase in CBR values. The air curing technique for curing the stabilized soil samples, instead of normal moist curing also plays an important role in the increase in strength as this keeps the w/c ratio within the desired level of 0.5. The results agree well with the findings of researchers (Tang, 2007; Tang, 2008) who have also reported an increase in strength with the addition of cement and fibers in clay.

However, in soil stabilized with cement and reinforced with fibers, the interactions between the fiber and the products of hydration contribute to the increase in the strength of the samples in general and fiber-soil interface in particular. The behavior of the fiber-soilhydration products is not understood clearly at this time and needs further evaluation.

\section{CONCLUSION}

In this study, peat soil has been stabilized with cement as binding agent alone and also stabilized with cement and polypropylene fibers as chemically nonactive additive. Air curing technique has been used to cure the peat soil samples stabilized with cement at normal room temperature and relative humidity and no water is added during the curing period. This air curing technique caused the stabilized peat soil samples to gradually lose their water content through curing period and become drier. The binding agent and the additive as well as the curing technique have proved to increase California Bearing Ratio (CBR) values of the stabilized peat soil samples tested after three months of curing period.

The result of CBR tests for stabilized peat soil with cement with different percentage of polypropylene fibers show that $0.15 \%$ is the optimum percentage to provide maximum CBR values. Curing the stabilized peat soil samples in air, will cause the moisture contents of the stabilized peat soil samples to be reduced through evaporation as well as hydration. Therefore watercement $(w / c)$ ratios of the samples reduce during curing process. As the w/c of the stabilized peat soils are reduced during the air curing period, the samples become drier and harder with increased CBR values.

As the cement amount is increased, the CBR values are increased. As expected, unsoaked CBR samples show more CBR values than soaked samples. As an example If only $15 \%$ of cement (less than $200 \mathrm{~kg} \mathrm{~m}^{-3}$ ) is mixed with peat soil and $0.15 \%$ (less than $2 \mathrm{~kg}$ ) polypropylene fibers, the CBR value of the undisturbed peat soil increases by a factor of over 22 for un-soaked condition and by a factor of over 15 for the soaked condition.

\section{ACKNOWLEDGEMENT}

The authors wish to express their gratitude to the Research University Grant Scheme, University Putra Malaysia, Malaysia (Project No. 91151) for the financial support to the research group. 


\section{REFERENCES}

Axelsson, K., S.E. Johansson and R. Erson, 2002. Stabilization of organic soils by cement and puzzolanic reactions-feasibility study. Swedish deep stabilization Research Centre, Report 3, 2002 English translation. http://www.swedgeo.se/sd/pdf/SD-R3E.pdf

Baisha, E.A., R. Hashim, H.B. Mahmud and A.S. Muntobar, 2005. Stabilization of residual soil with rice husk ash and cement. Construct. Build. Mater., 19: 448-453.

Black, A.J., V. Sivakumar, R.M. Madhav and A.G. Hamil, 2007. Reinforced stone column in weak deposit: Laboratory model study. J. Geotechn. Geoenviron. Eng., ASCE., 133: 1154-1161.

http://cat.inist.fr/?aModele=afficheN\&cpsidt=1902 0864

Bowles, J.E., 1978. Engineering Properties of Soil and Their Measurements. 2nd Edn., McGraw-Hill, United States, New York, ISBN: 007006752X pp: 312 .

British Standards Institution 1337, 1990. Methods of Test for Soils for Civil Engineering Purposes. London, BS 133710.

Chen, L. and D.F. Lin, 2009. Stabilization treatment of soft subgrade soil by sewage sludge ash and cement. J. Hazard. Mate., 162: 321-327. DOI: 10.1016/J.JHAZMAT.2008.05.060

Department of the Army, 1980. Engineering and Design Laboratory Testing Engineer. No 11102-21906, USA.

Duraisamy, Y., B.B.K. Huat, R. Muniandy and A.A. Abdul, 2006. Effect of cement column on the compressibility of tropical peat soil. Proceeding of the GSM-IEM Oktober forum on Engineering Geology and Geotechnical Engineering. Petalang Jaya, Malaysia.

http://www.eng.upm.edu.my/web080903/.../kawpu b2006bm.pdf

Hebib, S. and R.E. Farrell, 2003. Some experiences on the stabilization of Irish peats. Can. Geoteh J., 40:107-120. DOI: 10.1139/T02-091

Huat, B.B.K., 2004. Organic and Peat Soils Engineering. 1st Edn., University Putra Malaysia, ISBN: 983-2871-08-8, pp: 5-11.

Huat, B.B.K. and H.A. Faisal, 2007. Ground Improvement Technology. 1st Edn., University Putra Malaysia, ISBN: 983-2871-08-5, pp: 105.

Ismail, M.A., H.A. Joer, W.H. Sim and M. Randolph, 2002. Effect of cement type on shear behavior of cemented calcareous soil. J. Geotech. Geoenviron. Eng., 128: 520-529.
Kalantari, B. and B.B.K. Huat, 2008. Peat soil stabilization using ordinary portland cement, polypropylene fibers and air curing technique. Elect. J. Geotech. Eng., Bund. J., pp: 1-13. http://www.ejge.com/2008/Ppr0888/Ppr0888.pdf

Kalantari, B. and B.B.K. Huat, 2009. Precast Stabilized Peat Columns to Reinforce Peat Soil Deposits. Elect. J. Geotech. Eng., Bund. B., 14: 1-15. http://www.ejge.com/2009/Ppr0915/Ppr0915.pdf

Kolias, S., V. Kasselouri-Rigopoulou and A. Karahalios, 2005. Stabilization of clayey soils with high calcium fly ash and cement. Cement Conc. Compos., 27: 301-313. DOI: 10.1016/J.CEMCONCOMP.2004.02.019

Mullik, K.A., P. Walia and N.S. Sharma, 2007. Application of Polypropylene Fiber Reinforced Concrete (PFRC) with vacuum processing. Proceeding of the Advances in Bridge Engineering, New Delhi, India.

Neville, A.M., 1996. Properties of Concrete. 4th Edn., Longman Malaysia, Malaysia, pp: 10.

Park, T. and S.A. Tan, 2005. Enhanced performance of reinforced soil walls by the inclusion of short fiber. Geotextiles and Geomembr., 23: 348-361. DOI: 10.1016/j.geotexmem.2004.12.002

Road Research Laboratory, 1975. Design of normal concrete mixes, road note No. 4. Department of the Environment, Building Research Establishment, Her Majesty's Stationary Office, United Kingdom, pp: 5-30.

Sika.com, Technical data sheet, 2007. Polypropylene Fibers, Version no. 0010. 5th Edn., Malaysia, pp: 1-7. http://www.sika.com.my/my-con-msdssikagard_render_system_vp.pdf

Sivakumar Babu, G.L., A.K. Vasudevan and S. Haldar, 2008. Numerical simulation of fiber-reinforced sand behavior. Geotextiles Geomembr., 26: 181-188. DOI: 10.1016/J.GEOTEXMEM.2007.06.004

Tang, C.B., W. Shi, W. Gao, Chen and Y. Cai, 2007. Strength and mechanical behavior of short polypropylene fiber reinforced and cement stabilized clayey soil. Geotextiles Geomembr., 25: 194-202. DOI: 10.1016/j.geotexmem.2006.11.002

Yetimoglu, T., M. Inanir and O.E. Inanir, 2004. A study on bearing capacity of randomly distributed fiber-reinforced sand fills overlying soft clay. Geotextiles Geomembr., 23: 174-183. DOI: 10.1016/J.GEOTEXMEM.2004.09.004 